\title{
Purification and Characterizations of Anti-Microbial Protein from Calotropis procera
}

\author{
Abhay Kumar*, Nagendra Singh and Prafulla Kumar \\ School of biotechnology, Gautam Buddha University Gautam Buddha Nagar (U.P), India \\ *Corresponding author
}

\section{A B S T R A C T}

Calotropis procera is strongly recommended in leprosy, hepatic and splenic enlargement, dropsy and worms. The latex is applied to painful joints nad swelling fresh leaves are also used for same purpose. Oil which the leaves have been boiled is applied to paralyzed part. The milky

\begin{tabular}{|l|}
\hline Ke y w or d s \\
Calotropis procera, \\
Soft-wooded, \\
Evergreen \\
\hline Article Info \\
\hline Accepted: \\
15 July 2019 \\
Available Online: \\
10 August 2019 \\
\hline
\end{tabular}
juice is used in India as purgative, while flowers are considered as digestive, stomachic, tonic and useful in cough, asthma catarish, loss of appetite and hepatitis. The root bark is used to promote secretion and to be useful in treating skin disease, enlargement of abdominal viscera, intestinal worms, ascites and ancesraca. The leaves of Aak are warmed and tied around any body organ in pain. It is practically useful in backache and I joint pains. Calotropis procera latex contain cardioids such as calotropin, calotoxin, uscherin, uscchardin, glycoside calotropaginin, choline, o-pyrocatechuric acid, benzoyllineolone, benzoylisoloneolane, uzariganinand syriogenis proteins such as osmotin, calotropin etc. Osmotropin and calotropin shows the antimicrobial activity against microbe. Here we were isolated a novel protein from latex using ionexchange and gel filter Ttration chromatography that shows the antimicrobial activity. Antimicrobial activity assay done against bacterial and fungi. The bacterial and fungi strains are collected from Gautam Buddha University Greater Noida (U.P). E. coli, S. enterica, Vibro sp. P. aeruginosa, Klebsiella pneumoniae, Fusarium sp. and saccharomyces sp. Microbe were used for antimicrobial assay at different $\mathrm{pH}$, temp, \& concentration. Protein are being crystalized for structural and functional application.

\section{Introduction}

Calotropis procera plant is a soft-wooded evergreen, perennial shrub. Common names of Calotropis procera is Akund, apple of sadom, auricular tree, gaint milkweed, mudra, rooster tree, rubber bush, small crown flower, sadom milkweed, swallow wort [English] Aak, akada [Hindi].

The medicinal value of Calotropis has been described in older pharmacopeias, it strongly recommended in leprosy, hepatic and splenic enlargement, dropsy and worms. The latex is applied to painful joints and swelling fresh leaves are also used for same purpose. The milky juice is also used in India as purgative.

Chemical screening of latex of Calotropis procera the latex revealed that the plant contain cardioids such as calotropin, calotoxin, uscherin, uscchardin, glycoside calotropaginin, choline, o-pyrocatechuric acid, benzoyllineolone, benzoylisoloneolane, 
uzariganin and syriogenis etc. The latex in Calotropis procera show the antidysenteric, antirheumatic, antinociceptive and antiinflammatory activity. The leaves of calotropis shows antioxidant and anti-microbial activity. The flowers show antisialogous activity. Basic objective of this study was Extraction, Purification, and functional characterization of antimicrobial proteins from Calotropis procera latex.

\section{Materials and Methods}

\section{Sample collection}

Calotoropis procera latex was obtained from the industrial area of Kasna Greater Noida (U.P). The latex contains protein and many other proteases and pigments. Latex is also rich compound such as salt, minerals, lipids, carbohydrates, and in particular complex membrane systems, which can be co-extracted with proteins and interfere with protein purification. So removal of these compounds was necessary for this purpose we made the modified buffer that also provide protein stability.

The modified buffer composition was $2 \mathrm{mM}$ PMSF (phenylmethanesulfonylfluoride), 100mM EDTA, $100 \mathrm{mM}$ Tris base (pH-8.0), $50 \mathrm{mM}$ Vitamin C \& $30 \%$ sucrose. The every component of modified buffer have specific roles PMSF is a serine protease inhibitor that inhibit the chymotrypsin, trypsin, thrombin and cysteine protease papain. PMSF does not inhibits metelo-protease such as most cysteine protease or aspartic protease these proteases inhibited by the metello-protease inhibitor such as EDTA. Tris provide the stability of the target protein with respect to $\mathrm{pH}$ and the buffering compound. Vitamin $\mathrm{C}$ is an antioxidant. The roles of sucrose reduce the "Nonspecific interaction" between proteins and stabilize the protein and help in prevent protein aggregation.
Fresh latex was collected from healthy plants by small incisions near the youngest leaves and left to flow off into modified buffer in order to obtain a mixture $1: 1(\mathrm{v} / \mathrm{v})$. The mixture was gently handled to maintain homogeneity during transport to the laboratory.

\section{Protein extraction}

The mixture of latex and buffer vigorously vortexes for $30 \mathrm{~min}$ at room temperature. Then sample was sonicated for $5 \mathrm{~min}$ at temperature 37 , amplitude $40 \%$, pulse $2 \mathrm{sec}$ on and $2 \mathrm{sec}$ off on ice. Then sample was centrifuged for 1 hour at $14500 \mathrm{rpm}$ and $4^{0} \mathrm{c}$.

The middle phase collected as total purified latex. The rubber particle and pallet centrifuged again. The upper phase transfer into new centrifuged tube and pallet and rubber particle was discarded. Sodium Azide was added as antifungal agent. The extract was left for 2 hours at $4 \mathrm{C}$.

The protein from the crude extract was precipitated by a gradient of saturated ammonium sulphate solution. The solution was centrifuged at $12000 \mathrm{rpm}$ for 20 minutes to get the protein pellet. This pellet was resuspended in minimum volume of buffer and was set on dialysis in a $3 \mathrm{kDa}$ membrane for 24 hours against buffer. The dialyzed protein was stored at $4^{\circ} \mathrm{C}$ for further purification.

Protein was purified with the help ion exchange and gel filtration chromatography. CMC 50 (GE healthcare) was used as an ion exchanger matrix for protein purification.

\section{Protein quantification and estimation}

The purified protein sample was quantified using Lowry method for protein quantification (Lowry, 1951) and the samples of the fraction were run on the SDS PAGE. 


\section{Antimicrobial activity}

Various microorganisms were used for the investigation which included bacterial and fungal strains. All the strains were obtained from Gautam Buddha University, Greater Noida, and Uttar Pradesh, India. Lurea Broth and YPD were used for Prokaryotic and Eukaryotic systems respectively.

Sterile Filter paper (What man No. 1) discs with $4 \mathrm{~mm}$ diameter were impregnated with different concentrations of the purified protein (10ul) and were incubated for 24 hours in case of bacterium and 72 hours in case of fungal strains. Amp and autoclaved distil water were used as positive and negative control during the investigation, respectively. Only few microorganisms showed activity against the protein and they were further carried for further characterization of the various property of the purified protein on various parameters as temperature and $\mathrm{pH}$. Activity was determined by radial diffusion assay again and zone of inhibition was measured by HI media Zonal scale.

\section{Results and Discussion}

\section{Quantification of purified protein}

Purified protein was quantified by using Lowry method. The absorbance measured at $650 \mathrm{~nm}$ determined for BSA protein concentrations ranging from 0.0 to $05 \mathrm{mg} / \mathrm{ml}$. A polynomial non linear equation describing the standard curve generated. Protein was tested against standard protein curve that shows the 1.6-2.0mg/ml (Fig. 4).

\section{Antimicrobial activity of the purified protein}

Antimicrobial activity of the purified protein performed against many bacteria shows response to the purified protein. Some bacteria were sensitive to purified protein, some bacteria not sensitive to purified protein some bacteria killed by the proteins. For the stability of protein many variations was applied such as $\mathrm{pH}$, temperature and concentration of the proteins. As the antimicrobial activity of the protein was judged against various microorganisms, but only bacterial strains responded to the various concentrations of the protein. Fungal strain did not respond to the protein. The inhibitory activity was measured as zone of inhibition on the bacteria showed a zone of inhibition while fungal pathogens were not affected by the protein (Fig. 5).

Antimicrobial activity of protein was tested against some common microorganisms and further characterization of protein was done at different temperature and $\mathrm{pH}$. Antimicrobial protein showed maximum activity at $\mathrm{pH} 7$ and minimum at $\mathrm{pH} 9$ and moderate at $\mathrm{pH} 4$.

It means that the protein is most active at $\mathrm{pH} 7$. The effectiveness of the protein was also studied at different temperatures and minimum activity was found at $45^{\circ} \mathrm{C}$ and maximum at $30^{\circ} \mathrm{Cand}$ moderate at $37^{\circ} \mathrm{c}$. It means that protein is most active at $30^{\circ} \mathrm{C}$.

While conclusion and future aspects of this study includes, more than 12,000 plant species contain latex, a milky fluid in which occur a wide range of proteins. As the latex is abundant in the green parts of the plant, it is thought to be produced and accumulated as a defence strategy against viruses, fungi and insects. Indeed, besides proteins involved in rubber biosynthesis, latex fluids have been shown to contain proteins implicated in plant defence and oxidative metabolism. Today, latex is considered as a promising source of pharmacologically active molecules that might be chemically modified to improve their effectiveness With regards to $C$. procera, although the pharmacological potential of its latex has well been proven, only few active latex molecules have been identified until today (Fig. 1-5 and Table 1). 
Fig.1 Chromatogram showing various fractions after IEC

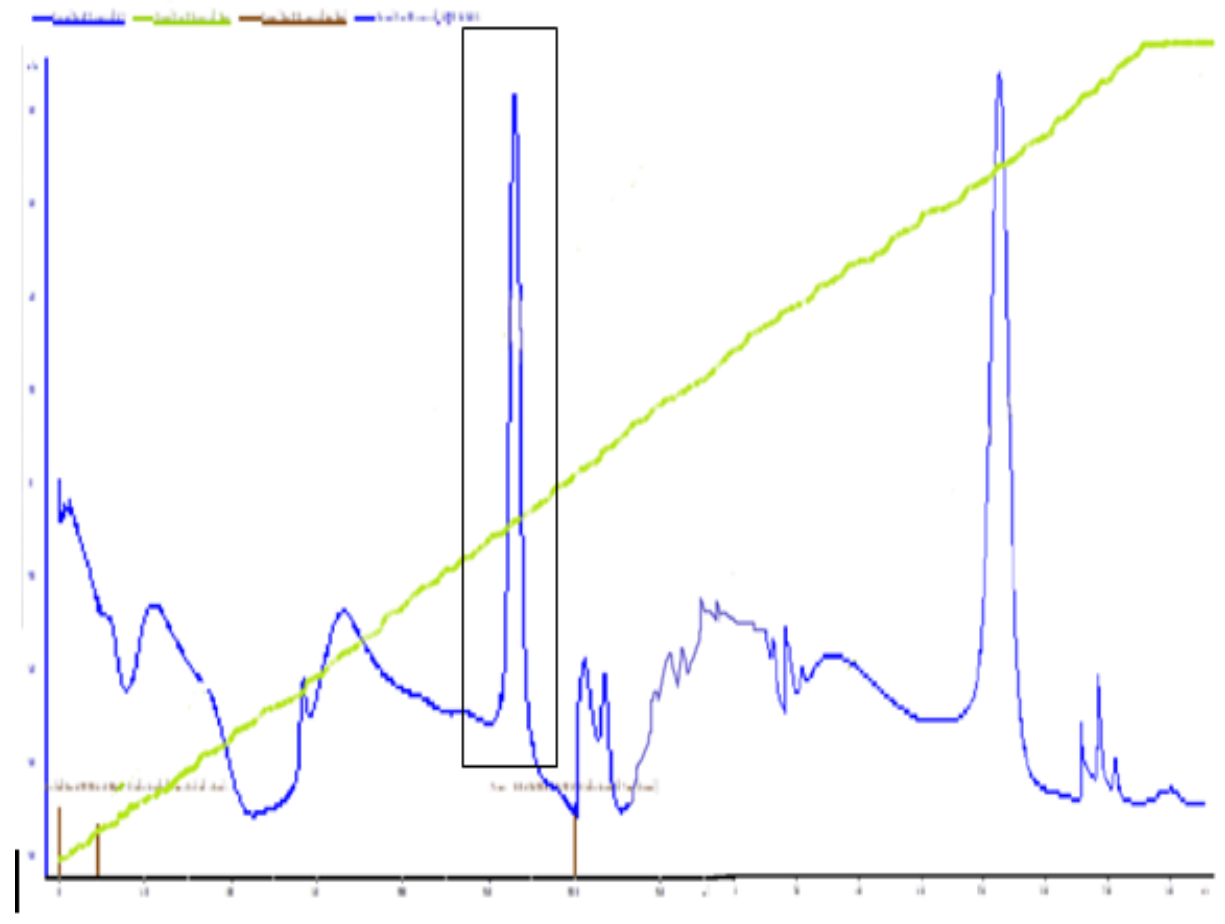

Fig.2 Chromatogram showing various O.D various fractions after IEC at $\lambda 280$ (series1) \& $\lambda 215$ (series2) on spectrophotometer

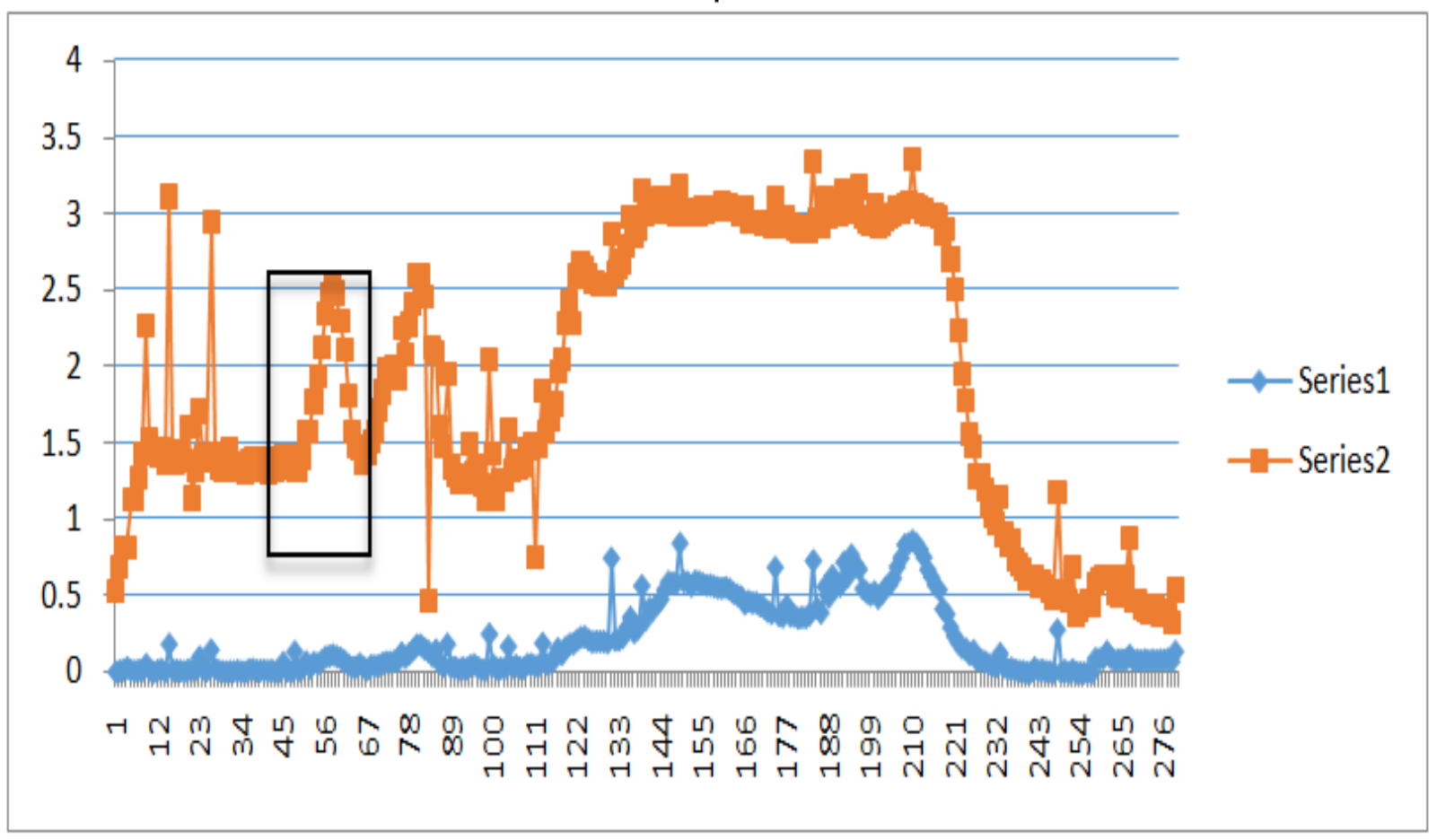


Fig.3 SDS PAGE of selected peaks of ion exchange chromatography

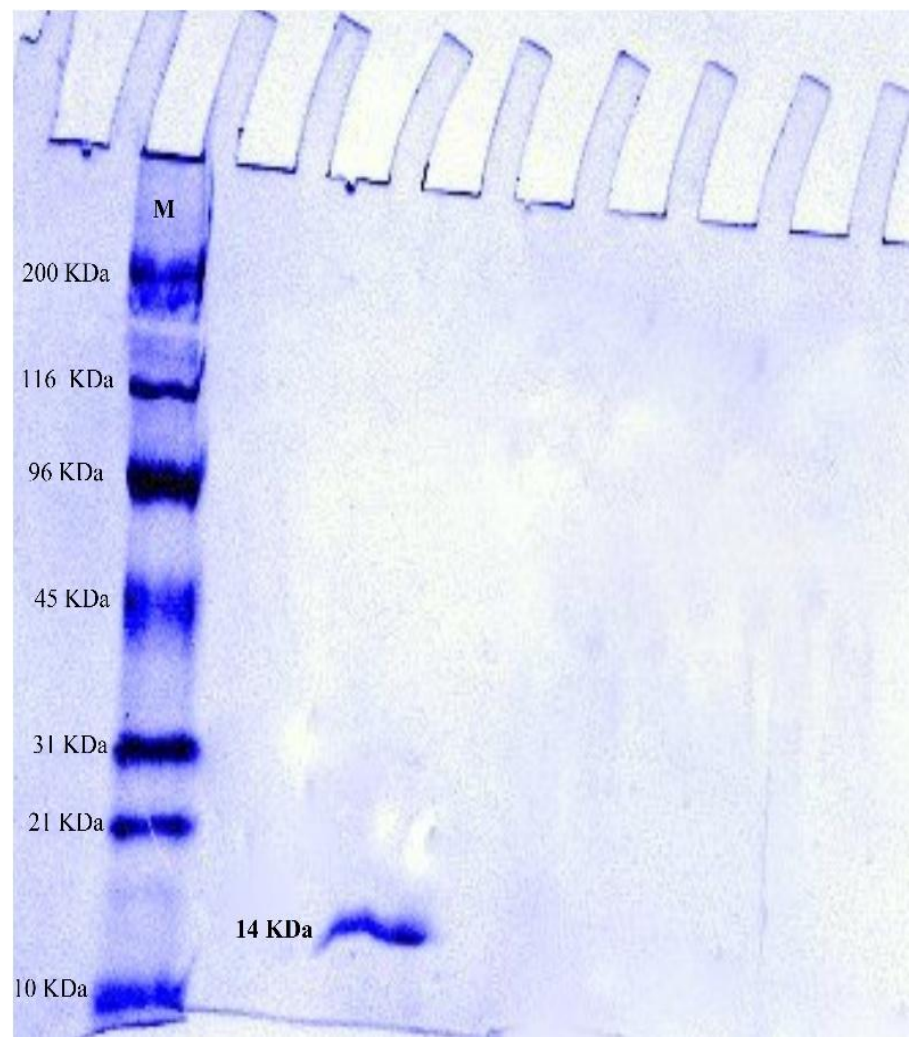

Fig.4 Standard curve for quantification of purified protein by lowry method

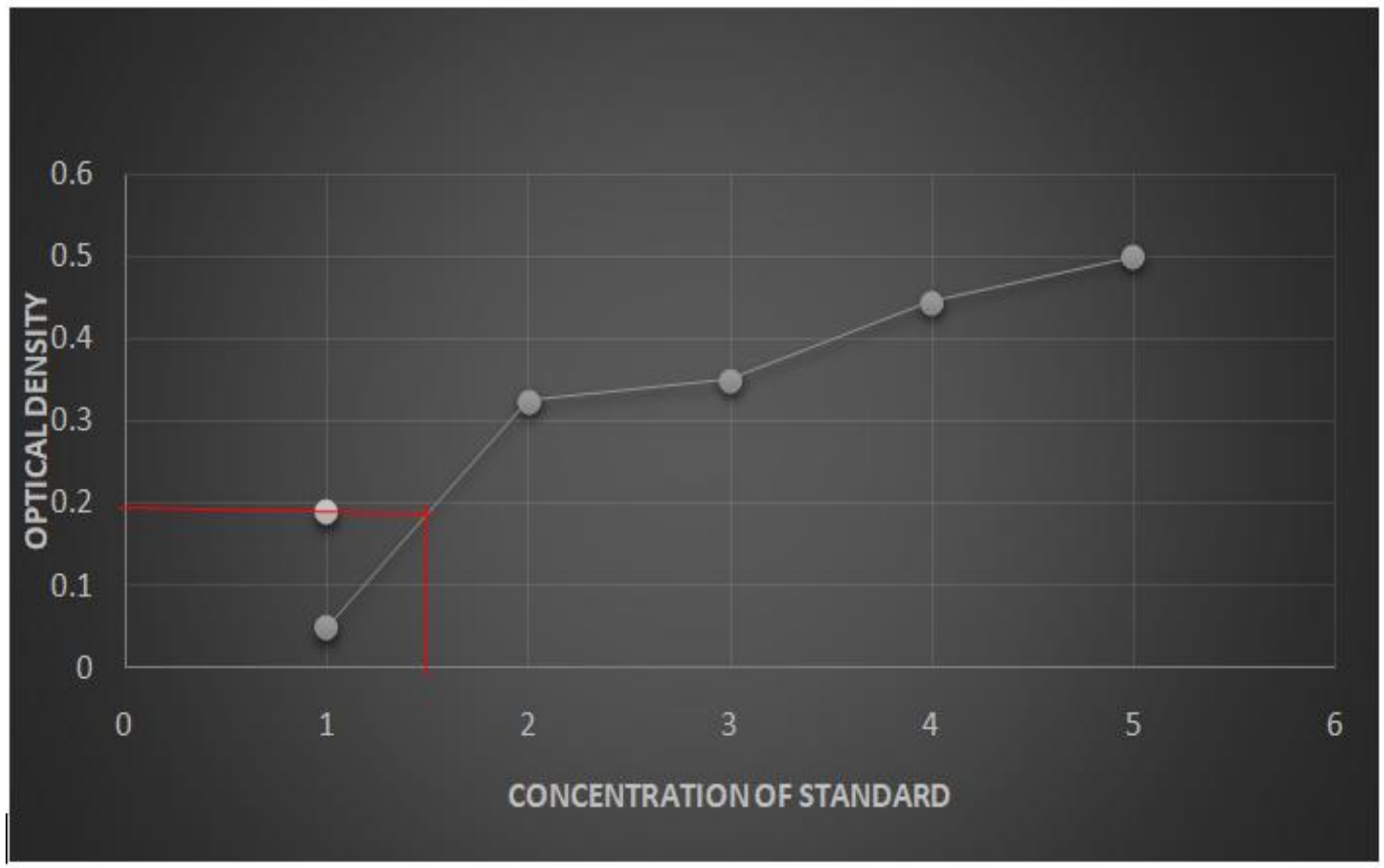



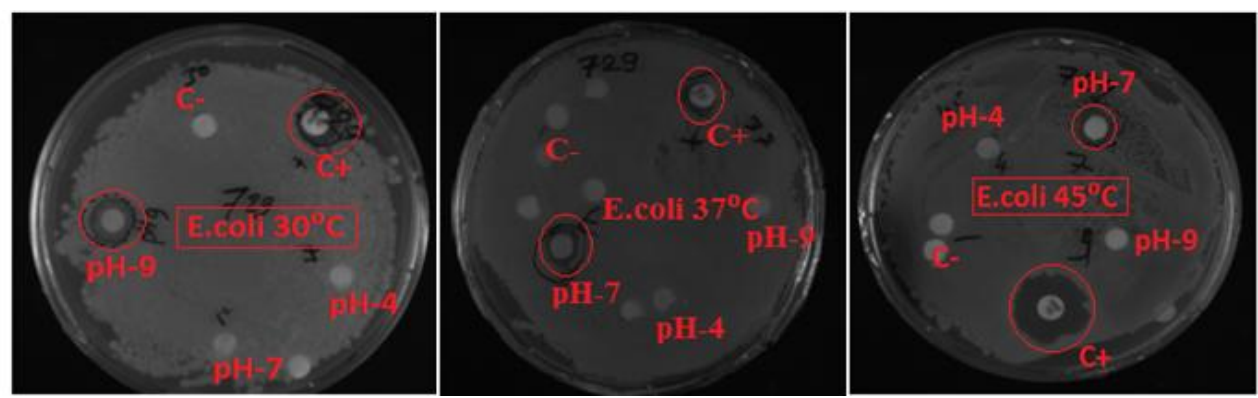

Figure - 5A. Antimicrobial activity of protein against E.coli at different $\mathrm{pH}(4,7 \& 9)$ and (A) $30^{\circ} \mathrm{C}(\mathrm{B}) 37^{\circ} \mathrm{C}$ and (C) $45^{\circ} \mathrm{C}$ temperature.
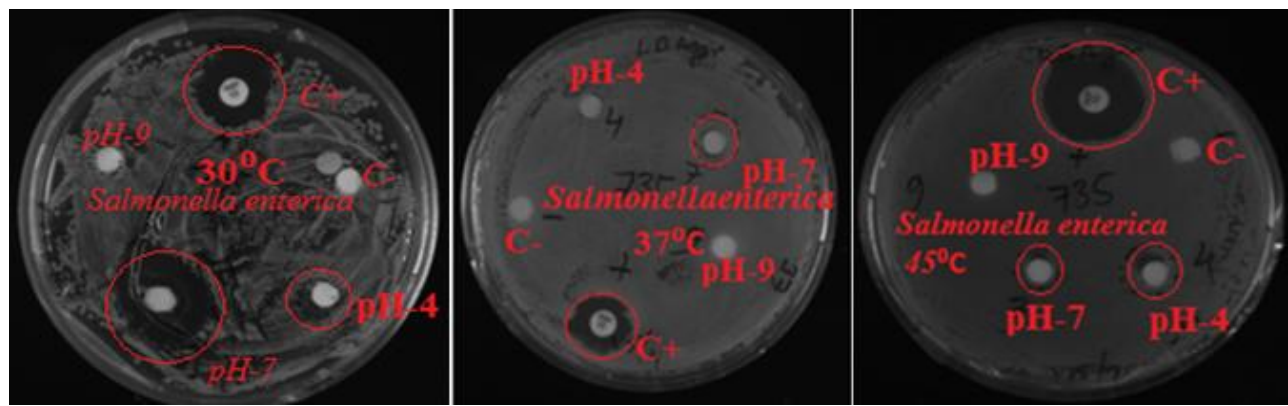

Figure - 5B. Antimicrobial activity of protein against Salmonella enterica at different $\mathrm{pH}(4,7 \& 9)$ and (A) $30^{\circ} \mathrm{C}$,(B) $37^{\circ} \mathrm{Cand}(\mathrm{C}) 45^{\circ} \mathrm{c}$ temperature.

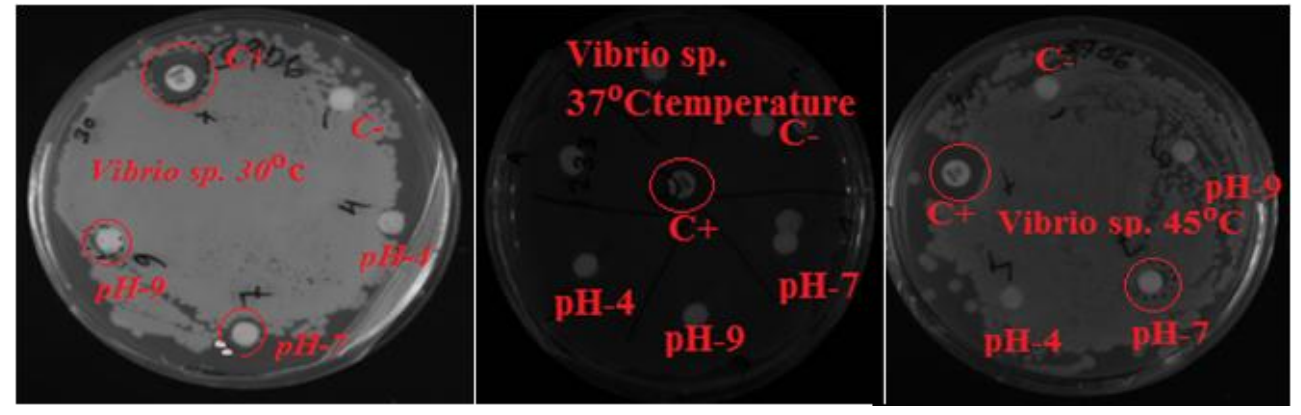

Figure - 5C. Antimicrobial activity of protein against Vibrio sp. at different $\mathrm{pH}(4,7 \& 9)$ and (A) $30^{\circ} \mathrm{C}$ and (B) $45^{\circ} \mathrm{Ctemperature.}$
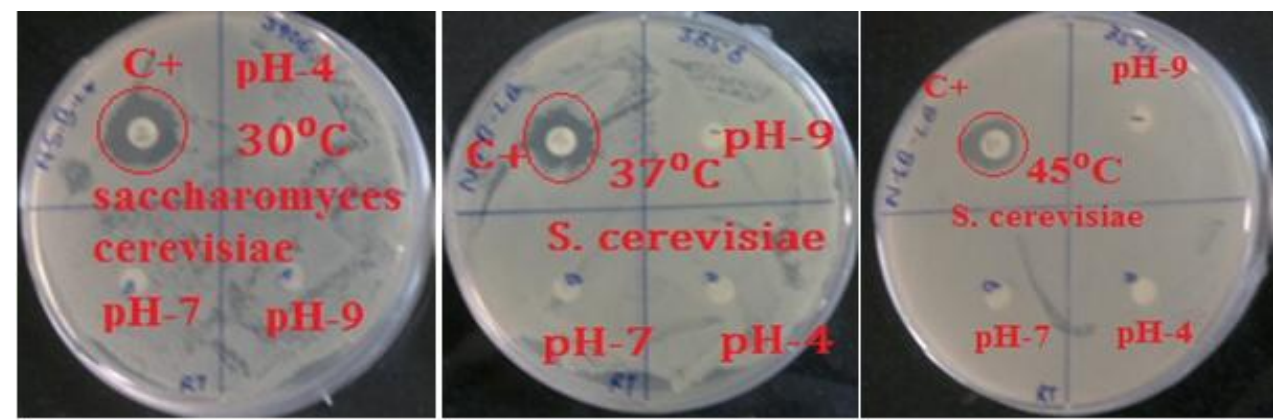

Figure - 5D. Antimicrobial activity of protein against saccharomyces cerevisiae at different $\mathrm{pH}(4,7 \& 9)$ and (A) $30^{\circ} \mathrm{C}$ and (B) $45^{\circ} \mathrm{Ctemperature.}$ 
Table.1 Antimicrobial activity of protein against different microbes at different $\mathrm{pH}$ and temperature in terms of zone of inhibition (in $\mathrm{mm}$ )

\begin{tabular}{|c|c|c|c|c|c|c|}
\hline Microrganisms & $\begin{array}{c}\text { Condition } \rightarrow \\
\text { Temperature } \\
\downarrow\end{array}$ & $\begin{array}{l}\text { POSITIVE } \\
\text { CONTROL } \\
(\mathrm{mm})\end{array}$ & $\begin{array}{c}\text { NEGATIVE } \\
\text { CONTROL } \\
(\mathrm{mm})\end{array}$ & $\begin{array}{l}\text { pH } 4 \\
(\mathrm{~mm})\end{array}$ & $\begin{array}{l}\text { pH } 7 \\
(\mathbf{m m})\end{array}$ & $\begin{array}{l}\text { pH } 9 \\
(\mathrm{~mm})\end{array}$ \\
\hline \multirow{3}{*}{$\begin{array}{c}\text { E.coli } \\
(M T C C \text { No.729) }\end{array}$} & $30^{\circ} \mathrm{C}$ & 10 & 0 & $\mathbf{0}$ & $\mathbf{0}$ & 11 \\
\hline & $37^{0} \mathrm{C}$ & 10 & $\mathbf{0}$ & $\mathbf{0}$ & 12 & $\mathbf{0}$ \\
\hline & $45^{\circ} \mathrm{C}$ & 17 & $\mathbf{0}$ & $\mathbf{0}$ & 10 & $\mathbf{0}$ \\
\hline \multirow{3}{*}{$\begin{array}{c}\text { Salmonella } \\
\text { enterica (MTCC } \\
\text { No.735) }\end{array}$} & $30^{\circ} \mathrm{C}$ & 18 & $\mathbf{0}$ & 12 & 23 & $\mathbf{0}$ \\
\hline & $37^{\circ} \mathrm{C}$ & 14 & $\mathbf{0}$ & $\mathbf{0}$ & 10 & $\mathbf{0}$ \\
\hline & $45^{\circ} \mathrm{C}$ & 12 & $\mathbf{0}$ & 12 & 10 & $\mathbf{0}$ \\
\hline \multirow{3}{*}{$\begin{array}{c}\text { Vibrio sp. } \\
\text { (MTCC } \\
\text { No.3906) }\end{array}$} & $30^{\circ} \mathrm{C}$ & 14 & $\mathbf{0}$ & $\mathbf{0}$ & 9 & 8 \\
\hline & $37^{0} \mathrm{C}$ & 12 & $\mathbf{0}$ & $\mathbf{0}$ & $\mathbf{0}$ & $\mathbf{0}$ \\
\hline & $45^{\circ} \mathrm{C}$ & 15 & $\mathbf{0}$ & 8 & $\mathbf{0}$ & $\mathbf{0}$ \\
\hline \multirow{3}{*}{$\begin{array}{c}\text { Saccharomyces } \\
\text { species }\end{array}$} & $30^{\circ} \mathrm{C}$ & 0 & $\mathbf{0}$ & $\mathbf{0}$ & $\mathbf{0}$ & $\mathbf{0}$ \\
\hline & $37^{\circ} \mathrm{C}$ & $\mathbf{0}$ & $\mathbf{0}$ & $\mathbf{0}$ & $\mathbf{0}$ & $\mathbf{0}$ \\
\hline & $45^{\circ} \mathrm{C}$ & 0 & $\mathbf{0}$ & $\mathbf{0}$ & $\mathbf{0}$ & $\mathbf{0}$ \\
\hline
\end{tabular}

The antimicrobial protein has been purified to homogeneity using chromatographic methods. The protein has been found inhibiting some bacterial species in vitro. The protein will be identified using sequencing approach and the will be expressed for further characterization and production in larger amount. This protein can be used as antibacterial agents as whole. The structural characterization of this protein will provide details about it antimicrobial function, which can be used for designing new antimicrobial agents to combat microbial infections.

\section{References}

Bashir A., Naseer M., Khatoon A. Identification of expansin variants from Calotropis procera seed fibers. EMBL AB030976.2

Bhattacharya D., Sengupta A., Sinha N.K. Chemical modification and amino terminal sequence of calotropin DI from Calotropis Gigantean. Phytochemistry 26:633636(1987)

Circosta C, Sanogo R, Occhiuto F, 2001. Effects of Calotropis procera on oestrous cycle and on oestrogenic 1089-8
Cleverson Diniz Teixeira de Freitas, José Luiz de Souza Lopes, Leila Maria Beltramini,

Hassan S W, Bilbis F L, Ladan M J, Umar R A, Dangoggo S M et al.,2006. Evaluation of antifungal activity and phytochemical analysis of leaves, roots and stem barks extracts of Calotropis procera (Asclepiadaceae), Pak J Biol Sci, 9(14), 2624-2629.

Jain PK, Verma R, Kumar N, Kumar A (1985) Clinical trial of Arka-Mulatwak-Bark of $C$. procera -a preliminary study. J Res Ayur Sidha 6: 88-91

Kumar S, Dewan S, Sangraula H, Kumar VL. Anti-diarrhoeal activity of the latex of Calotropis procera. $\mathrm{J}$ Ethnopharmacol 2001; 76: 115-8.

Kumar VL, Shivkar YM. In vivo and in vitro effect of latex of Calotropis procera on gastrointestinal smooth muscles. J Ethnopharmacol 2004; 93: 377-9.

Lima-Filho JV, Patriota JM, Silva AF, Filho NT, Oliveira RS, et al., (2010) Proteins from latex of Calotropis procera prevent septic shock due to lethal infection by Salmonella enterica serovar Typhimurium. $\mathrm{J}$ Ethnopharmacol 129: 327-334. doi: 10.1016/j.jep.2010.03.038

Mireille Faurobert, Esther Pelpoir, and Jamila 
Chaïb. Phenol Extraction of Proteins for Proteomic Studies of Recalcitrant Plant Tissues

Mossa JS, Tariq M, Mohsin A, Ageel AM, alYahya MA, et al., (1991) Pharmacological studies on aerial parts of Calotropis procera. Am J Chin Med 19: 223-231. doi: 10.1142/s0192415x91000302

Nallamsetty S, Kundu S, Jagannadham MV. Purification and biochemical characterization of a highly active cysteine protease ervatamin A from the latex of Ervatamia coronaria. J Protein Chem 2003; 22: 1-13.

Oliveira JS, Costa-Lotufo LV, Bezerra DP, Alencar NM, Marinho-Filho JD, et al., (2010) In vivo growth inhibition of sarcoma 180 by latex proteins from Calotropis procera. Naunyn Schmiedebergs Arch Pharmacol 382: 139-149. doi: 10.1007/s00210-010-0525-6

Parveen I., Singh H.K., Raghuvanshi S., Babbar S.B. DNA barcoding of Orchids. Prasad G (1985) Action of Calotropis procera on migraine. J Nati Integ Med Assoc 27: 710

Posch A, Chen ZP, Wheeler C, Dunn MJ, RaulfHeimsoth M, Baur X: Characterization and identification of latex allergens by twodimensional electrophoresis and protein microsequencing. J Allergy Clin Immunol 1997, 99: 385-395.

R.B. Ferreira, S. Monteiro, R. Freitas, C.N. Santos, Z. Chen, L.M. Batista, J. Duarte, A. Borges, A.R. Teixeira, The role of plant defense proteins in fungal pathogenesis, Mol. Plant Pathol. 8 (2007) 677-700.

R.M. Epand, H.J. Vogel, Diversity of antimicrobial peptides and their mechanisms of action, Biochim. Biophys.
Acta 1462 (1999) 11-28.

Ramadan A.M., Shokry A.M., Gadallah N.O., Hassan S.M., Edris S., Al-Kordy M.A., Abuzinadah O.A., Sabir J.M., Al-Akilli R.S., Al-Zahrani H.M., Hussein R.M., ElDomyati F.M., Bahieldin A. Detection of a MAPK-like gene in Calotropis procera plant from the de novo assembled genome contigs of the high throughput sequencing dataset. Life Sci J 9: 157-166 (2012)

Raquel Sombra Basílio de Oliveira, José Tadeu Abreu Oliveira, Márcio Viana Ramos. Osmotin from Calotropis procera latex: New insights into structure and antifungal properties

Saravanan, R. S. and Rose, J. K. C. (2004) A critical evaluation of sample extraction techniques for enhanced proteomic analysis of recalcitrant plant tissues. Proteomics 4, 2522-2532.

Sennblad B., Bremer B. Classification of Apocynaceae s.l. according to a new approach combining Linnean and Phylogenetic Taxonomy

Sharma P, Sharma JD. Evaluation of in vitro schizontocidal activity of plant parts of Calotropis procera-an ethnobotanical approach. J Ethnopharmacol 1999; 68: 8395.

Shu YZ. Recent natural products based drug development: a pharmaceutical industry perspective. J Nat Prod 1998; 61: 1053-71.

Singh A.N., Yadav P., Dubey V.K. cDNA Cloning and Molecular Modeling of Procerain B, a Novel Cysteine Endopeptidase Isolated from Calotropis procera. PLoS ONE 8:E59806-E59806 (2013).

\section{How to cite this article:}

Abhay Kumar, Nagendra Singh and Prafulla Kumar. 2019. Purification and Characterizations of Anti-Microbial Protein from Calotropis procera. Int.J.Curr.Microbiol.App.Sci. 8(08): 17541761. doi: https://doi.org/10.20546/ijcmas.2019.808.207 